\title{
Joy Edelman
}

J oy Edelman, who died on 10 July 2004 at the age of 66, was one of the pioneer DGH cardiologists in the UK. Joy graduated from the London Hospital Medical School in 1961 and maintained strong links with the London Hospital and with her previous classmates. She did her pre-registration surgical house job at King George Hospital, Ilford, and returned there as a consultant physician 12 years later. She had had postgraduate training in cardiology at the National Heart Hospital and was a contemporary and close colleague of, among others, Raphael Balcon, Derek Gibson, and Jane Somerville. When Joy got to King George Hospital there were essentially no local cardiology services. She set about developing them and soon, first in the old hospital and then later, managed to develop a large coronary care unit and dedicated non-invasive department in the new hospital in Goodmayes in 1993. She managed to get a second cardiologist there in 1996, and a permanent pacing service was set up in 1997.

Even after retiring from a full time post in 1999, Joy worked behind the scenes to secure the provision of a cardiac catheterisation laboratory. The cardiac catheterisation laboratory was

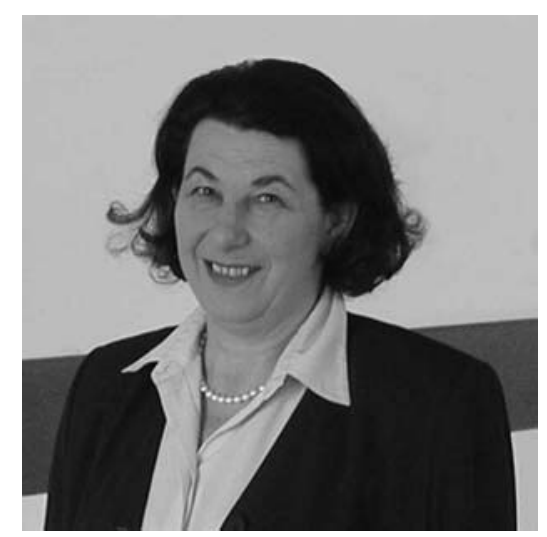

opened in November 2003 and in recognition of all her hard work for the hospital the cardiology unit, including the cardiac catheterisation laboratory, was renamed the Joy Edelman Department of Cardiology.

Joy worked tirelessly for her colleagues in the political arena. She spent five years as chair of the Medical Division at King George Hospital and six years as the chair of the Senior Staff Medical Committee. She chaired the North East Thames Regional Consultant and Specialists Committee and Regional Manpower Committee of the BMA between 1994 and 1998. She remained a member of the Regional Task Force up until her retirement. She had spells on the BMA Council and the Council of the Royal College of Physicians and worked extremely hard for the BMA. She was chair of the Central Manpower Committee from 1992 to 1994 and of the hospital Senior Staff Conference from 1996 to 1998. She was a member of the editorial board of the British National Formulary and a member of the Department of Health Working Parties on women in medicine and flexible training.

In 2003 Joy was delighted to be one of the first two recipients ever of the BMA Medal for Service to the BMA. This was thoroughly deserved.

In addition to her major influence in medicine and cardiology, Joy was a valued friend and colleague to many and an extremely important mentor for many young doctors. She showed loyalty and kindness to all those who worked with her and to her many patients. She is greatly missed by all those who knew her.

R Hall, A Deaner roghall1@aol.com 